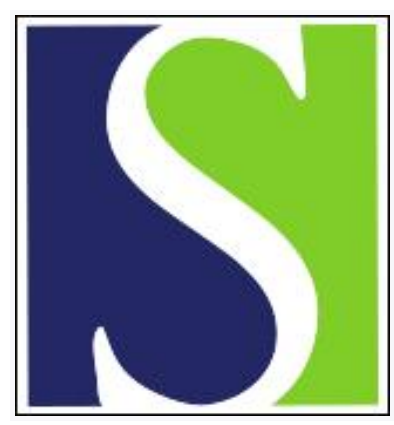

Scand J Work Environ Health 1992;18(2):128-132

https://doi.org/10.5271/sjweh.1600

Issue date: 01 Apr 1992

Antibodies against Yersinia among farmers and slaughterhouse workers.

by Seuri M, Granfors K

Affiliation: Department of Community Health and General Practice, University of Kuopio, Finland.

This article in PubMed: www.ncbi.nlm.nih.gov/pubmed/1604274

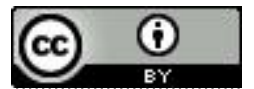




\title{
Antibodies against Yersinia among farmers and slaughterhouse workers
}

\author{
by Markku Seuri, MD, ${ }^{1}$ Kaisa Granfors, $\mathrm{PhD}^{2}$
}

\begin{abstract}
SEURI M, GRANFORS K. Antibodies against Yersinia among farmers and slaughterhouse workers. Scand J Work Environ Health 1992;18:128-132. Antibodies to immunoglobulins (Ig) M, G, and A against Yersinia enterocolitica serotypes O:3, O:5, O:8, and O:9 and Yersinia pseudotuberculosis serotypes I and III were analyzed by enzyme immunoassay of the serum samples of 161 slaughterhouse workers, 147 pig farmers, and 114 grain or berry farmers. The crude risk ratios for elevated serum antibody concentrations were calculated with the use of the grain and berry farmers as the reference population. The risk for an elevated $Y$ enterocolitica $\mathrm{O}: 3 \mathrm{Ig} \mathrm{G}$ concentration was 3.0 (95\% confidence interval $(95 \% \mathrm{CI}) 1.3-7.1)$ for the pig farmers and $1.8(95 \% \mathrm{CI} 0.7-4.4)$ for the slaughterhouse workers and the respective risks for elevated $Y$ enterocolitica $\mathrm{O}: 9 \mathrm{Ig}$ G were $2.4(95 \% \mathrm{CI} 1.1-5.5)$ and $1.7(95 \%$ CI $0.7-4.0)$. Since these two serotypes are commonly associated with swine, the increased number of subjects with elevated antibody levels could be causally related to occupational contact with this animal.
\end{abstract}

Key terms: agricultural workers, epidemiology, farming, occupational, zoonosis.

A comprehensive review published in 1988 lists 20 occupational zoonoses found among agricultural workers who breed animals. In addition, nine zoonoses were associated with workers in facilities which process animal products (1). Yersinia species were not included in either group. In a recent Finnish study, slaughterhouse workers were observed to have elevated antibody levels against $Y$ enterocolitica $\mathrm{O}: 3$ twice as frequently as blood donors, and it was concluded that yersinia infections are an occupational health risk to workers slaughtering swine in slaughterhouses (2). There is only one report in Russian concerning Yersinia spp and agricultural work, but no detailed figures are given in it (3).

$Y$ enterocolitica has been isolated from several different animal species, animal products, and a variety of inanimate reservoirs, including lakes, streams, vegetables, and soil (4). Swine is a recognized reservoir for human pathogenic Y enterocolitica in Europe and Japan, where serotypes $0: 3$ and $0: 9$ have been isolated from the tongue, throat, tonsils, cecal contents, and feces of swine (5-8).

The most common clinical manifestation of yersinosis is enterocolitis, which may mimic appendicitis. Focal extraintestinal infections and bacteremia are less common occurrences. Even if enterocolitis is generally seen in young children, the postinfection complications, including reactive arthritis and erythema nodosum, occur mainly in adults (4).

1 University of Kuopio, Kuopio, Finland.

${ }^{2}$ University of Turku, Turku, Finland.

Reprint requests to: Dr M Seuri, University of Kuopio, Department of Community Health and General Practice, POB 1627, SF-70211 Kuopio, Finland.
The documented transmission of $Y$ enterocolitica to humans has occurred primarily through the ingestion of contaminated foods, water, and milk (4). The consumption of contaminated raw pork has been suspected to account for many sporadic cases of infection (4), but the documentation supporting this suspicion is scarce. In Belgium, the consumption of raw pork was found to be associated with Y enterocolitica infections (9). Outbreaks of such infections have been caused by well or spring water $(10,11)$ and contaminated milk (12-14). There is no documentation of outbreaks associated with contaminated pork. Household preparation of chitterlings made of pig intestines caused an outbreak of $15 Y$ enterocolitica O:3 infections in the United States (15). In Finland, outbreaks have been documented among nurses caring for patients with yersinia diarrhea and among patients in the same hospital wards $(16,17)$, as well as among families of patients (18).

The documented prevalence of Yersinia isolation from swine is high in Denmark, where $80-100 \%$ of swine is reported to harbor $Y$ enterocolitica in their tonsils (19). The percentage of swine herds from which the isolation of $Y$ enterocolitica succeeded from the tonsils in the southwest of Finland is 35 (20). The reported prevalences depend on the isolation methods employed $(21,22)$.

The purpose of this study was to determine whether occupational groups in close contact with swine production or swine slaughtering could have an increased risk of elevated antibody content to the common pathogenic $Y$ enterocolitica and $Y$ pseudotuberculosis serotypes. In occupations which have close contact with swine (ie, among pig farmers and slaughterhouse workers) an elevated risk was found for a high anti- 
body content of $Y$ enterocolitica $0: 3$ and $0: 9$ in the immunoglobulin ( $\mathrm{Ig}$ ) $\mathrm{G}$ class.

\section{Subjects and methods}

One hundred and seventy-two persons working on the kill floor of six swine-processing slaughterhouses situated in central and northern Finland were asked to participate. Blood samples were obtained from $161(94 \%)$ of these persons.

The pig farmers studied came from a smaller geographic area, the Kuopio district, in the eastern part of Finland. The pig farmers were chosen from the register of the local cooperative meat-processing company, which covers virtually all the swine producers in the area. Those farmers involved in milk or beef production were excluded, in addition to those who were over 65 years of age. One hundred and fortyseven (71\%) pig farmers, out of the 206 invited, participated in the blood sampling.

The farmers comprising the reference population lived in the same area, but their main line of production was either grain or berries with no pork, beef, or milk production. They were identified from the register of the local agricultural advisory association, which covers about $60-80 \%$ of the farmers in the district. One hundred and fourteen $(70 \%)$ blood samples were obtained from the 162 farmers of the reference population invited to take part.

Only one serum sample per farm was taken. All of the farms were run by owner families, and, in each case, the family member who spent the most time tending the swine, grain, or berries was asked to take part in the sampling.

Finally, 200 blood donor samples from the same geographic area as the farmers (the Kuopio district) were obtained with which the cutoff point for the antibody positivity was determined. No other information regarding the donors (ie, age, gender) was known.

In general, the slaughterhouse workers were somewhat younger than the farmers. However, within the 35- to 55-year-old age bracket, which covered the majority of the subjects, there were no marked differences between the groups (table 1). There were 33 $(22 \%)$ women among the pig farmers, $17(11 \%)$ among the slaughterhouse workers, and $14(12 \%)$ among the grain and berry farmers. Almost half $(48 \%)$ of the slaughterhouse workers were smokers at the time of the blood sampling in comparison with $24 \%$ of the pig farmers and $17 \%$ of the grain and berry farmers.

The Ig M, Ig G, and Ig A antibodies to $Y$ enterocolitica O:3, O:5, O:8, and $\mathrm{O}: 9$ and $Y$ pseudotuberculosis I and III were measured by enzyme immunoassay (23). The preparation of sodium dodecyl sulfate extracts of whole Yersinia bacteria to be used as antigen has been described elsewhere (24). Polystyrene microtiter plates (Nunc, Roskilde, Denmark) were coated with bacterial antigens in phosphate buffered saline (PBS) $(0.1 \mathrm{~mol} / 1, \mathrm{pH} 7.5,100 \mu \mathrm{l} /$ well). The plates were saturated with $1 \%$ normal sheep serum in PBS $(100 \mu \mathrm{l} /$ well $)$.

Patient serum samples at a dilution of 1:250 were incubated on the plates for $2 \mathrm{~h}$ at $37^{\circ} \mathrm{C}$. Thereafter, For each well $75 \mu \mathrm{l}$ of swine antihuman Ig M, Ig G, or Ig A conjugated with alkaline phosphatase (Orion Diagnostica, Espoo, Finland), diluted 1:250, 1:300, and 1:250, respectively, was incubated on the plates overnight at room temperature. Freshly prepared p-nitrophenol phosphate in a buffer solution of diethanolamine and magnesium chloride $(1 \mathrm{mg} / \mathrm{ml}$; Orion Diagnostica) was added and incubated for $30 \mathrm{~min}$ at $37^{\circ} \mathrm{C}$. The reaction was stopped with $1 \mathrm{M}$ sodium hydroxide. The optical density was measured with a Titertek Multiscan Photometer (Labsystems, Helsinki, Finland) at a wavelength of $405 \mathrm{~nm}$. The results were given in enzyme immunoassay units (EIU) compared with a strongly positive reference serum: $1 \mathrm{U}$ was $1 / 100$ of the corresponding antibody concentration in the reference serum. The samples were tested as duplicates, and the results were expressed as mean values. The serum samples were analyzed in three series, each containing blood donor samples, but otherwise the analyzing laboratory did not know from which study group the samples originated.

The cutoff point for the antibody positivity of different serotypes in the three Ig classes was determined from the results of the 200 blood donor samples. The cutoff point was chosen to be the mean of all the blood donor samples plus two standard deviations of the mean.

Analyzing four serotypes of $Y$ enterocolitica and two serotypes of Y pseudotuberculosis in three Ig classes yielded 18 different sets of results. Possible crossreactions were investigated from a correlation matrix of results expressed in EIU. In the same way, possible cross-positivities were looked for in the cross-tabulation of the positive values of different analyses.

No attempt was made to standardize the crude risk ratios. The relative risk (or risk ratio) of Yersinia antibody positivity was calculated with its $95 \%$ confidence interval $(95 \% \mathrm{CI})(25)$.

Table 1. Age distribution of the pig farmers, slaughterhouse workers, and grain and berry farmers.

\begin{tabular}{|c|c|c|c|c|c|c|}
\hline \multirow[t]{2}{*}{$\begin{array}{l}\text { Age group } \\
\text { (years) }\end{array}$} & \multicolumn{2}{|c|}{$\begin{array}{c}\text { Pig } \\
\text { farmers }\end{array}$} & \multicolumn{2}{|c|}{$\begin{array}{c}\text { Slaughter- } \\
\text { house } \\
\text { workers }\end{array}$} & \multicolumn{2}{|c|}{$\begin{array}{c}\text { Grain and } \\
\text { berry } \\
\text { farmers }\end{array}$} \\
\hline & $\mathrm{N}$ & $\%$ & $N$ & $\%$ & $N$ & $\%$ \\
\hline $\begin{array}{l}<25 \\
25-34 \\
35-44 \\
45-55 \\
56-65\end{array}$ & $\begin{array}{r}3 \\
33 \\
55 \\
36 \\
19\end{array}$ & $\begin{array}{r}2 \\
22 \\
37 \\
24 \\
13\end{array}$ & $\begin{array}{r}10 \\
45 \\
64 \\
38 \\
3\end{array}$ & $\begin{array}{r}6 \\
28 \\
40 \\
24 \\
2\end{array}$ & $\begin{array}{r}2 \\
14 \\
37 \\
27 \\
32\end{array}$ & $\begin{array}{r}2 \\
13 \\
32 \\
24 \\
28\end{array}$ \\
\hline Not known & 1 & 1 & 1 & 1 & 2 & 2 \\
\hline
\end{tabular}


Table 2. Number and percentage of the grain and berry farmers, swine farmers, and slaughterhouse workers who were positive for $Y$ enterocolitica $0: 3,0: 5,0: 8,0: 9$ or $Y$ pseudotuberculosis 1 or III in the immunoglobulin (1g) G, A, or M classes and the relative risks (RR) for elevated antibody levels with their $95 \%$ confidence intervals $(95 \% \mathrm{Cl})$ for the swine farmers and slaughterhouse workers.

\begin{tabular}{|c|c|c|c|c|c|c|c|c|c|c|}
\hline \multirow{2}{*}{$\begin{array}{l}\text { Bacteria and } \\
\text { serotype }\end{array}$} & \multicolumn{2}{|c|}{$\begin{array}{l}\text { Grain and } \\
\text { berry farmers }\end{array}$} & \multicolumn{4}{|c|}{ Pig farmers } & \multicolumn{4}{|c|}{ Slaughterhouse workers } \\
\hline & $\mathrm{N}$ & $\%$ & $N$ & $\%$ & RR & $95 \% \mathrm{Cl}$ & $\mathrm{N}$ & $\%$ & RR & $95 \% \mathrm{Cl}$ \\
\hline \multicolumn{11}{|c|}{ Y enterocolitica $0: 3$} \\
\hline $\begin{array}{l}\lg G \\
\lg A \\
\lg M\end{array}$ & $\begin{array}{r}6 \\
10 \\
12\end{array}$ & $\begin{array}{r}5 \\
9 \\
11\end{array}$ & $\begin{array}{l}23 \\
21 \\
18\end{array}$ & $\begin{array}{l}16 \\
14 \\
12\end{array}$ & $\begin{array}{l}3.0 \\
1.6 \\
1.2\end{array}$ & $\begin{array}{l}1.3-7.1 \\
0.8-3.3 \\
0.6-2.3\end{array}$ & $\begin{array}{l}15 \\
10 \\
17\end{array}$ & $\begin{array}{r}9 \\
6 \\
11\end{array}$ & $\begin{array}{l}1.8 \\
0.7 \\
1.0\end{array}$ & $\begin{array}{l}0.7-4.4 \\
0.3-1.6 \\
0.5-2.0\end{array}$ \\
\hline \multicolumn{11}{|c|}{ Y enterocolitica 0:5 } \\
\hline $\begin{array}{l}\lg G \\
\lg A \\
\lg M\end{array}$ & $\begin{array}{r}17 \\
8 \\
2\end{array}$ & $\begin{array}{r}15 \\
7 \\
2\end{array}$ & $\begin{array}{r}21 \\
8 \\
8\end{array}$ & $\begin{array}{r}14 \\
5 \\
5\end{array}$ & $\begin{array}{l}1.0 \\
0.8 \\
3.1\end{array}$ & $\begin{array}{l}0.5-1.7 \\
0.3-2.0 \\
0.7-14.3\end{array}$ & $\begin{array}{r}17 \\
14 \\
7\end{array}$ & $\begin{array}{r}11 \\
9 \\
4\end{array}$ & $\begin{array}{l}0.7 \\
1.2 \\
2.5\end{array}$ & $\begin{array}{l}0.4-1.3 \\
0.5-2.9 \\
0.5-11.7\end{array}$ \\
\hline \multicolumn{11}{|c|}{$Y$ enterocolitica $0: 8$} \\
\hline $\begin{array}{l}\lg G \\
\lg A \\
\lg M\end{array}$ & $\begin{array}{r}17 \\
27 \\
6\end{array}$ & $\begin{array}{r}15 \\
24 \\
5\end{array}$ & $\begin{array}{l}27 \\
27 \\
13\end{array}$ & $\begin{array}{r}18 \\
18 \\
9\end{array}$ & $\begin{array}{l}1.2 \\
0.8 \\
1.7\end{array}$ & $\begin{array}{l}0.7-2.1 \\
0.5-1.2 \\
0.7-4.3\end{array}$ & $\begin{array}{r}35 \\
21 \\
8\end{array}$ & $\begin{array}{r}22 \\
13 \\
5\end{array}$ & $\begin{array}{l}1.4 \\
0.6 \\
0.9\end{array}$ & $\begin{array}{l}0.9-2.5 \\
0.3-0.9 \\
0.3-2.6\end{array}$ \\
\hline \multicolumn{11}{|c|}{$Y$ enterocolitica $0: 9$} \\
\hline $\begin{array}{l}\lg G \\
\lg A \\
\lg M\end{array}$ & $\begin{array}{r}7 \\
14 \\
7\end{array}$ & $\begin{array}{r}6 \\
12 \\
6\end{array}$ & $\begin{array}{r}22 \\
25 \\
7\end{array}$ & $\begin{array}{r}15 \\
17 \\
5\end{array}$ & $\begin{array}{l}2.4 \\
1.4 \\
0.8\end{array}$ & $\begin{array}{l}1.1-5.5 \\
0.8-2.5 \\
0.3-2.1\end{array}$ & $\begin{array}{l}17 \\
26 \\
12\end{array}$ & $\begin{array}{r}11 \\
16 \\
7\end{array}$ & $\begin{array}{l}1.7 \\
1.3 \\
1.2\end{array}$ & $\begin{array}{l}0.7-4.0 \\
0.7-2.4 \\
0.5-3.0\end{array}$ \\
\hline \multicolumn{11}{|c|}{ Y pseudotuberculosis I } \\
\hline $\begin{array}{l}\lg G \\
\lg A \\
\lg M\end{array}$ & $\begin{array}{r}15 \\
8 \\
5\end{array}$ & $\begin{array}{r}13 \\
7 \\
4\end{array}$ & $\begin{array}{l}18 \\
10 \\
10\end{array}$ & $\begin{array}{r}12 \\
7 \\
7\end{array}$ & $\begin{array}{l}0.9 \\
1.0 \\
1.6\end{array}$ & $\begin{array}{l}0.5-1.8 \\
0.4-2.4 \\
0.5-4.4\end{array}$ & $\begin{array}{r}15 \\
6 \\
12\end{array}$ & $\begin{array}{l}9 \\
4 \\
7\end{array}$ & $\begin{array}{l}0.7 \\
0.5 \\
1.7\end{array}$ & $\begin{array}{l}0.4-1.4 \\
0.2-1.5 \\
0.6-4.7\end{array}$ \\
\hline \multicolumn{11}{|c|}{ Y pseudotuberculosis III } \\
\hline $\begin{array}{l}\lg G \\
\lg A \\
\lg M\end{array}$ & $\begin{array}{r}22 \\
21 \\
3\end{array}$ & $\begin{array}{r}11 \\
18 \\
3\end{array}$ & $\begin{array}{r}25 \\
25 \\
3\end{array}$ & $\begin{array}{r}17 \\
17 \\
2\end{array}$ & $\begin{array}{l}0.9 \\
0.9 \\
0.9\end{array}$ & $\begin{array}{l}0.5-1.5 \\
0.5-1.6 \\
0.2-3.8\end{array}$ & $\begin{array}{r}22 \\
33 \\
5\end{array}$ & $\begin{array}{r}14 \\
20 \\
3\end{array}$ & $\begin{array}{l}0.7 \\
1.1 \\
1.2\end{array}$ & $\begin{array}{l}0.4-1.2 \\
0.7-1.8 \\
0.3-4.8\end{array}$ \\
\hline
\end{tabular}

Table 3. Correlation matrix for antibodies against $Y$ enterocolitica $O: 3$ and $0: 9$ in the immunoglobulin $(\mathrm{lg}) \mathrm{G}$ class and for antibodies against $Y$ enterocolitica $0: 5$ in the $\lg M$ class.

\begin{tabular}{lcc}
\hline & $\begin{array}{c}Y \text { enterocolitica } \\
0: 3 \mathrm{lgG}\end{array}$ & $\begin{array}{c}Y \text { enterocolitica } \\
0: 9 \mathrm{IgG}\end{array}$ \\
\cline { 2 - 3 }$Y$ & 0.37 &. \\
Y enterocolitica $0: 9 \mathrm{IgM}$ & 0.15 & 0.15 \\
\hline
\end{tabular}

Table 4. Number of observed and expected jointly positives of $Y$ enterocolitica serotypes $0: 3$ and $0: 9$ in the immunoglobulin (Ig) $\mathrm{G}$ class and $0: 5$ serotype in the IgM class.

\begin{tabular}{|c|c|c|c|c|}
\hline & \multicolumn{2}{|c|}{$\begin{array}{c}Y \text { enterocolitica } \\
0: 3 \mathrm{lgG}\end{array}$} & \multicolumn{2}{|c|}{$\begin{array}{c}Y \text { enterocolitica } \\
0: 9 \mathrm{lgG}\end{array}$} \\
\hline & $\begin{array}{l}\text { Observed } \\
(\mathrm{N})\end{array}$ & $\begin{array}{l}\text { Expected } \\
\text { (N) }\end{array}$ & $\begin{array}{l}\text { Observed } \\
\text { (N) }\end{array}$ & $\begin{array}{l}\text { Expected } \\
\text { (N) }\end{array}$ \\
\hline $\begin{array}{l}\text { Y enterocolitica } \\
0: 9 \mathrm{lgG}\end{array}$ & 8 & 4.8 & . & . \\
\hline $\begin{array}{l}Y \text { enterocolitica } \\
0: 5 \operatorname{IgM}\end{array}$ & 5 & 1.8 & 5 & 1.8 \\
\hline
\end{tabular}

\section{Results}

The most remarkable differences between the groups were found for the Ig $\mathrm{G}$ class antibodies against $Y$ enterocolitica serotypes O:3 and O:9 and for Ig M class antibodies against $Y$ enterocolitica $\mathrm{O}: 5$ (table 2). The risk ratio of positive $Y$ enterocolitica $\mathrm{O}: 3 \mathrm{Ig} \mathrm{G}$ antibodies was 3.0 (95\% CI 1.3-7.1) for the pig farmers and $1.8(95 \% \mathrm{CI} 0.7-4.4)$ for the slaughterhouse workers when compared with values of the grain and berry farmers. The risk ratios of the positive $Y$ enterocolitica O:9 Ig G antibodies were $2.4(95 \% \mathrm{CI}$ $1.1-5.5)$ and $1.7(95 \% \mathrm{CI} 0.7-4.0)$, respectively. The number of positives in the $Y$ enterocolitica $\mathrm{O}: 5 \mathrm{Ig} \mathrm{M}$ class was only 17 and resulted in the extension of the confidence intervals. The risk ratio of positivity in this class was $3.1(95 \% \mathrm{CI} 0.7-14.3)$ for the pig farmers and $2.5(95 \%$ CI $0.5-11.7)$ for the slaughterhouse workers in comparison with the value of the grain or berry farmers.

The risk ratios comparing pig farmers or slaughterhouse workers to the farmers of the reference population remained below two for the other antibody groups, as the data in table 2 suggest.

The correlations of antibody values expressed in EIU for the three antibodies, when the risk ratios exceeded two, were rather low, as seen in table 3. Table 4 shows the numbers of observed and expected jointly positives of the same serotypes.

\section{Discussion}

$Y$ enterocolitica $0: 3$ and $0: 9$ are the two serotypes associated with swine (4). The workers in occupations which involved close contact with swine had more frequently elevated Ig $\mathrm{G}$ class antibodies against these 
serotypes. The Ig G class is the type which stays elevated for the greatest length of time after yersinosis with no postinfectious arthritis (26). In the case of Yersinia-triggered reactive arthritis both Ig A and, to a less extent, Ig G stay elevated (26). In a previous Finnish study, $11(50 \%)$ of 22 enteritis patients who did not suffer from arthritis and $28(72 \%)$ of 39 subjects with reactive arthritis were found to have Ig G class antibodies against $Y$ enterocolitica $0: 3$ at 1216 months after the onset of the infection. For the Ig A class antibodies the respective results were $7(32 \%)$ for the nonarthritis cases and $33(85 \%)$ for the arthritis subjects (27). However, it is not known how long Ig $\mathrm{G}$ antibodies persist after entirely asymptomatic enteric infection.

Although the number of subjects in this study was relatively limited, the $95 \%$ confidence interval of the risk ratios of $Y$ enterocolitica $\mathrm{O}: 3 \mathrm{Ig} \mathrm{G}$ and $\mathrm{O}: 9 \mathrm{Ig} \mathrm{G}$ positivity were above unity for the pig farmers. For the slaughterhouse workers, the risk ratios might have been biased because the slaughterhouse workers had a more urban way of living than the rural reference population. Thus the risk of positivity could have been underestimated for the slaughterhouse workers.

The increased risk of positivity of $Y$ enterocolitica O:5 Ig M class observed among the pig farmers and the slaughterhouse workers might be a result of the marked cross-positivity between $Y$ enterocolitica O:5 Ig M with both $Y$ enterocolitica $\mathrm{O}: 3 \mathrm{Ig} \mathrm{G}$ and $Y$ enterocolitica $\mathrm{O}: 9 \mathrm{Ig} \mathrm{G}$, as seen in table 4. On the other hand, the correlations of the antibody concentration expressed in EIU were rather low between these groups, and therefore suggest that the cross-positivity was not primarily due to cross-reactivity in the analysis, but rather caused by some external factor which is a common determinant of the three $Y$ enterocolitica serotypes. However, when the wide confidence intervals are taken into account, the elevated risk ratio of Ig M class antibodies against $Y$ enterocolitica $\mathrm{O}: 5$ might be a product of chance.

The results of this study are somewhat similar to the findings of Merilahti-Palo et al (2) in a previous study of butchers living in the southwest of Finland. In that study, slaughterhouse workers were found to have an increased number of antibodies against $Y$ enterocolitica $0: 3$, but not against the other serotypes tested, namely, Y enterocolitica $0: 9$ and Y pseudotuberculosis IA and III (2). Even if the method of selecting the cutoff value between elevated and "normal" antibody concentration was similar to ours, there were some differences in the study design and analysis. In the design, we used blood donors only for the evaluation of the cutoff value. Merilahti-Palo et al used blood donors as the reference group. In our study the comparability of effects and populations (28) was more valid for the comparison of pig farmers with grain or berry farmers, but, as has already been discussed, the comparison with slaughterhouse workers with farmers may be biased.
In the analysis, Merilahti-Palo et al considered a subject to have antibodies against Yersinia if he or she was found to be positive in any one of the three Ig classes. For $Y$ enterocolitica $0: 3$ the greatest difference between the slaughterhouse workers and the blood donors was in the Ig A class (9\% positives among the slaughterhouse workers versus $3 \%$ among the blood donors). For the $\mathrm{Ig} \mathrm{G}$ class the respective percentages were 9 and 6 (2). Expressed in terms of the risk ratio, this finding means 1.5 , which is about the same as we observed, namely, 1.8.

Our results show that occupational contact with swine is associated with an increased number of workers having elevated antibody concentrations against those $Y$ enterocolitica serotypes found in swine. This association was found to be more obvious among pig farmers than among slaughterhouse workers. Whether diseases caused by these serotypes of $Y$ enterocolitica are more prevalent in occupations involving contact with swine needs to be studied.

\section{Acknowledgments}

We are indebted to Professor K Aho and Professor $\mathrm{K}$ Husman for their valuable comments on the manuscript and to Ms T Manuel for her assistance in improving the language.

This study was supported by the Finnish Work Environment Fund (contract 8851), by the Farmers' Social Insurance Institution of Finland (contract 0101), and by the Academy of Finland.

\section{References}

1. Dutkiewicz J, Jablønski L, Olenchock A. Occupational biohazards: a review. Am J Ind Med 1988;14:605-23.

2. Merilahti-Palo R, Lahesmaa R, Granfors K, GripenbergLerche C, Toivanen P. Risk of Yersinia infection among butchers. Scand J Infect Dis 1991; 23:55-61.

3. Kolos EN, Gnutov IN, Iushchenko GV, Dunaev VI. Agricultural animals as the sources of yersinosis. $\mathrm{Zh}$ Mikrobiol Epidemiol Immunobiol 1985;4:77-80.

4. Cover TL, Aber RC. Yersinia enterocolitica. N Engl J Med 1989;321:16-24.

5. Wauters G. Carriage of Yersinia enterocolitica serotype 3 by pigs as a source of human infection. Contrib Microbiol Immunol 1979;5:249-52.

6. Fukushima $\mathbf{H}$, Nakumura R, Ito $\mathbf{Y}$, Tsubokura $\mathbf{M}$, Otsuki K. Ecological studies of Yersinia enterocolitica: I. dissemination of Y. enterocolitica in pigs. Vet Microbiol 1983;8:469-83.

7. Hunter D, Hughes S. Isolation of Yersinia enterocolitica from pigs in the United Kingdom. Vet Rec 1983; 112:322-3.

8. Aldová E. Svandová E. Yersinia enterocolitica 03 findings on porcine tongues in comparison with yersinosis incidence in man in Czechoslovakia. J Hyg Epidemiol Microbiol Immunol 1984;28:319-29.

9. Tauxe RV, Vandepitte J, Wauters G, Martin SM, Goossens V, De Mol P, et al. Yersinia enterocolitica infections and pork: the missing link. Lancet 1987;1:112932. 
10. Lassen J. Yersinia enterocolitica in drinking-water. Scand J Infect Dis 1972;4:125-7.

11. Tacket CO, Ballard J, Harris N, Allard J, Nolan C, Quan T, et al. An outbreak of Yersinia enterocolitica infections caused by contaminated tofu (soybean curd). Am J Epidemiol 1985;121:705-11.

12. Black RE, Jackson RJ, Tsai T, Medvesky M, Shayegani $M$, Feeley JC, et al. Epidemic Yersinia enterocolitica infection due to contaminated chocolate milk. N Engl J Med 1978;298:76-9.

13. Tacket CO, Narain JP, Sattin R, Lofgren JP, Konigsberg C, Rendtorff RC, et al. A multistate outbreak of infections caused by Yersinia enterocolitica transmitted by pasteurized milk. JAMA 1984;251:483-6.

14. Hughes D. Yersinia in the dairy industry. Contrib Microbiol Immunol 1987:9;22-5.

15. Lee LA, Cerber AR, Lonsway DR, Smith JD, Carter GP, Puhr ND, et al. Yersinia enterocolitica O:3 infections in infants and children associated with the household preparation of chitterlings. N Engl J Med 1990; 322:984-7.

16. Toivanen P, Toivanen A, Olkkonen L, Aantaa S. Hospital outbreak of Yersinia enterocolitica infection. Lancet 1973;1:801-3.

17. Leino R, Granfors K, Aantaa S, Toivanen A. Yersiniainfektiot sairaalan henkilökunnassa [Yersinia infections among hospital personnel]. Suom Lääkäril 1983;38: $3151-2$.

18. Ahvonen P, Rossi T. Familial occurrence of Yersinia enterocolitica infection and acute arthritis. Acta Paediatr Scand Suppl 1970;206:121-2.

19. Christensen SG. The Yersinia enterocolitica situation in Denmark. Contrib Microbiol Immunol 1987;9:93-7.

20. Asplund K, Tuovinen V, Veijalainen, Hirn J. The prevalence of Yersinia enterocolitica O:3 in Finnish pigs and pork. Acta Vet Scand 1990;31:39-43.

21. Wauters G, Goossens V, Janssens M, Vandepitte J. New enrichment method for isolation of pathogenic Yersinia enterocolitica serogroup O:3 from pork. Appl Environ Microbiol 1988;54:851-4.

22. Nesbakken T. Comparison of sampling and isolation procedures for recovery of Yersinia enterocolitica serotype 0:3 from the oral cavity of slaughter pigs. Acta Vet Scand 1985;26:127-35.

23. Granfors K. Measurement of immunoglobulin M (Ig M), Ig $\mathrm{G}$ and $\mathrm{Ig} \mathrm{A}$ antibodies against Yersinia enterocolitica by enzyme-linked immunosorbent assay: persistence of serum antibodies during disease. J Clin Microbiol 1979;9:336-41.

24. Granfors K, Lahesmaa-Rantala R, Ståhlberg TH, Toivanen $A$. Comparison of bacteria with and without plasmid-encoded proteins as antigens for measurement of immunoglobulin M, G, and A antibodies to Yersinia enterocolitica by enzyme-linked immunosorbent assay. J Clin Microbiol 1989;27:583-5.

25. Morris JA, Gardner MJ. Calculating confidence intervals for relative risks, odds ratios, and standardised ratios and rates. In: Gardner MJ, Altman DG, ed. Statistics with confidence - confidence intervals and statistical guidelines. London: British Medical Journal, 1989: $50-63$.

26. Granfors $\mathrm{K}$, Viljanen M, Tiilikainen A, Toivanen A. Persistence of Ig M, Ig G and Ig A antibodies to Yersinia in Yersinia arthritis. J Infect Dis 1980;141:424-9.

27. Toivanen A, Lahesmaa-Rantala R, Vuento R, Granfors $K$. Association of persisting IgA response with Yersinia triggered reactive arthritis: a study on 104 patients. Ann Rheum Dis 1987;46:898-901.

28. Miettinen OS. Theoretical epidemiology. New York, NY: John Wiley \& Sons, 1985:30-4.

Received for publication: 17 May 1991 